\title{
ELECTRONIC PAYMENT SYSTEMS USE AND SATISFACTION IN AN ARABIC COUNTRY: EVIDENCE FROM KUWAIT
}

\author{
Kamel Rouibah, College of Business Administration, Kuwait University, krouibah@cba.edu.kw
}

\begin{abstract}
Despite that existence of variety of electronic payment systems is among critical success factors of ecommerce, it is surprising to note that few studies were carried about the preferences of customers to these alternatives. This study evaluates the degree of current use, satisfaction, intention to adopt and perceived obstacles toward existing electronic payment systems. Data were collected from 350 consumers in Kuwait with regard to thirteen available electronic payment systems. Results reveal that the most used systems are debit cards, credit cards, cash on delivery, shop and ship service, prepaid Petronet card and mobile payment. Systems that received high satisfaction are payment with debit cards, credit cards, cash on delivery, shop and ship service, payment with prepaid Petronet and mobile payment. Payment systems that consumers intent to use in the future are: prepaid CashU.com, payment over Civil ID, cash on delivery Shop and Ship service, PayPal, and internet prepaid bank cards.
\end{abstract}

Keywords: Electronic Payment System, Online Payment, Use of Electronic Payment, Satisfaction, Obstacles

\section{INTRODUCTION}

Retails e-commerce revenue is increasing annually at an estimate of $15 \%$ between 1995 and 2016 from less than $\$ 20$ billion to more than $\$ 550$ billion 23. And according to recent statistics the total of ecommerce including B2C, B2B, $\mathrm{C} 2 \mathrm{C}$ and mobile commerce is close to $\$ 13$ trillion 10 .

This increase depends on the availability and acceptance of a variety of electronic payment systems (noted here EPS) by customers, besides other factors. Electronic payment is defined as the transfer of an electronic value of payment from a payer to a payee through an e-payment mechanism. EPS has become one of the most critical issues for successful business and financial services 443. Availability of different EPSs is a factor that contributes to the success of e-commerce web sites, besides other factors such as level of IT infrastructure in a target country, legal business regulation, level of computer-skills, acceptance of IT solutions, and preferences of customers. Compare to traditional cash payment, EPSs have several favorable characteristics including reliability, scalability, anonymity, acceptability, efficiency, and convenience 639.

Although EPSs bring benefits to both vendors and customers, they also have limitations. First, the system creates physical separation between buyers and sellers, and between buyers and merchandise. Second, despite much systems are available, surveys establish that cash is still the most preferred way of payment since close to $80 \%$ of payment transactions are still made of cash specially in less developed countries 2218. Also EPSs suffer from other barriers including perceived risk and lack of trust 621363742, privacy and usability/ acceptability, and many studies proposed recommendations on how to increase EPS adoption; however these recommendations did not follow a customer centric and provide empirical data 19242529 while other only focus on describing exiting EPSs 82039. In addition, very few studies investigated which EPS are most used by customers and receive satisfaction and what obstacles do consumers perceive when they use them 4041. It is also worthwhile to mention that little research has been done on the diffusion of EPS in developing countries such as Ghana 2, Malaysia 30 and Arab countries 3541. Accordingly the existence of variety of EPS is questioned in term of use, satisfaction and perceived obstacles.

In order to increase our knowledge EPS perceptions (use, satisfaction and obstacles) this study sheds light on the issues from an Arab perspective through the following five questions: (i) What EPSs do exist in Kuwait which enable customer to engage in ecommerce activities? (ii) What EPSs are mostly used in Kuwait? (iii) What EPSs receive more satisfaction in Kuwait? (iv) What EPSs, not currently in use, will be used in the next 12 coming months? (v) What obstacles do customers perceive in Kuwait?

\section{LITERATURE REVIEW}




\section{Status of Information and Communication Technologies in Kuwait}

Kuwait is a small Arab country with 17820 square kilometers that includes 3.65 million habitants. Internet is widely spread in Kuwait with 1.96 million internet users, making it the third Arab country, among 22 countries in term of internet penetration $74.20 \%$ after Qatar (86.20\%) and Bahrain (77\%), and mobile phone penetration (143\%) 9 . Kuwait is also ranked 63 out of 198 countries by the United Nation in global e-government 2012, and fourth in the Arab world after United Arab Emirates (rank 28); Bahrain (Rank 36); Saudi Arabia (rank 41), Qatar (48). In addition, Kuwait ranks fourteenth globally and first among Arab countries in internet connection services. In addition, Kuwait spend annually huge amount to improve its ICT. For example, a recent report predicts that the total volume expenditure in ICT will reach $\$ 28$ billion between 2011 and 2015. These numbers make Kuwait among the leader in the Arab world in term of internet based applications such as e-government, e-payments, e-commerce, mobile commerce, and mobile payments.

\section{Categories of Electronic Payment in Kuwait}

There is a variety of EPS that can be classified into three categories: prepaid, pay now and pay-later systems 39. These three types are offered in Kuwait which were previously described and portrayed 34.

\section{Prepaid Systems}

Are systems that take away a certain amount of money from a customer before making purchases. Several types of prepaid systems exist in Kuwait. Payment over civil-ID card is a new service in Kuwait where people who have a smart Civil ID can charge their cards and use it as an EPS. This was mainly designed to hold personal information as well to expand in the future into an electronic wallet. Currently soor.com, a gasoline station company, uses it as well as Boubyan bank. But it is expected that it will gain more widespread as Kuwait is currently moving toward a cashless society. Other competing companies Petronet Smart Network Company KSCC also offer prepaid fuel cards that can be recharged from the internet. Internet bank prepaid cards are issued by the ten national commercial banks also offer prepaid cards which can be used to complete purchases either inside or outside the country. In addition, these banks provide online banking in order to meet the requirements of e-commerce, such as transfer between bank accounts, international transfers, pays mobile phone bills. CashU.com is another online payment service provider that offers prepaid payment. This is a famous Arab online payment system that enables potential customers to complete their ecommerce purchases only outside the country. CashU belongs to Maktoob.com, a famous Arab Internet service company. This company started its business in three Arab countries (Jordan, Kuwait and UEA) in 2001 and then spread in more than 52 countries distributed over the five continents. This company has 584 sales points in Kuwait. It is very convenient for customers who are willing to purchase from internet but do have only cash. They can open an account with CashU, refill it and then use it as an EPS since it is accepted by lot of e-stores such as Amazon.com.

\section{Pay Now Systems}

These are systems that debit the account of the customer at the exact time the customer completes purchases. It includes a variety of systems in Kuwait such as. Debit cards managed by K-net Company. This is the most used and accepted debit card in Kuwait. Recently it was also expanded to cover the GCC market where consumers from the six countries can use it to complete their purchases. And this card is used by all ATM machines in Kuwait and GCC countries. Self-service e-kiosk is another service provided by the government of Kuwait where consumers can pay their bills related to electricity and water, telecommunication, e-stamps, etc. These e-kiosks are located in wellknown locations such as shopping mauls and supermarket. According to the CEO of Knet, a famous e-payment company in Kuwait, "Knet completed the fiscal year of 2013 by more than 145 million payment transactions over its network and a total of \$35.1 billion Kuwaiti dinars through a variety of electronic communications including POS, ATM's, payment gateway, electronic and other online. With an average of 12 million payment transactions/month during this period". Debit cards are be use to do shopping in many places, such as paying bills of mobile phones service providers in Kuwait (e.g. though Zain gateway), internet service providers (e.g. QualityNet), entertainment services (e.g. Kuwait Cinescape), buying and selling stocks from the Kuwaiti stock market. Mobile payment is another debit EPS. Early 2005 a Kuwaiti company initiated this service which last for three year 35 . However this 


\section{Issues in Information Systems \\ Volume 16, Issue II, pp. 149-160, 2015}

service was not a successful case and the company stopped its service in 2008. But starting 2009 the Knet Company re-launched the mobile payment service. It is now used by four companies in Kuwait: Ooredoo mobile service company, ISYS mobi, Fono Mobile Communication. For example customers can pay their bus tickets via mobile phone through Boloro platform. Other companies offer possibilities for customers to make their purchases through mobile phones (e.g. Next.com). These developments have advanced people behavior toward more online shopping and use of EPSs. Tasdeed is the official electronic payment gate of the e-government of Kuwait (www.e.gov.kw). This system is used by nine public ministries and allow individuals to pay online bills (e.g. electricity and water) and violations (e.g. traffic, Civil ID violation). Other debit EPS systems are also available for Kuwaiti consumers include paying with PayPal and Western MoneyZap. Additional debit systems in Kuwait include Enet, a quick payment service from Automated Services Network Co (www.e.net.kw), where customers can pay their bill or buy online services. Cameoo.com is another online payment system for e-shoppers in Kuwait that sells many prepaid card in Kuwait.

\section{Pay Later Systems}

These are also known as "post payment" systems in which the customer actually receives the goods before his account is debited. These systems can be classified in two types: credit cards and cash on delivery (COD). Credit cards are well known electronic payment systems and have emerged more than three decades. There exist different systems such as MasterCard and Express American. It involves transmitting the customer's transaction information to the merchant, since neither the card nor the customer is visible to the merchant. COD systems are well-known too in Kuwait and start to receive wide acceptance as they overcome the security and trust issues. The customer orders some articles delivered by a third party. The customer pays cash on delivery. Three services are offered in Kuwait: Just Ask, Shop and Ship and World Shop. These services enable customer to shop from outside Kuwait, if they are not willing to pay with their credit cards or don't have such cards, and then pay on delivery once the product is shipped to Kuwait. Aramex shop \& Ship from Aramex (www.aramex.com) enables its customers to purchase from Web sites in Europe, North America, South Africa and China only. The company provides customers with an official post code address needed to if a customer decide to purchase from one of these countries. Through this post code a customer can purchase what he wants and Aramex will deliver the product to Kuwait. Just Ask is a service provided by Sultan Center (www.sultan-center.com), a famous retail company. This is an interesting and convenient alternative in situations where customers cannot find goods in local market and perceive internet security problems, or do not have a credit card to pay electronically. Customers in need of this service approach a store of Sultan centre, request what they want. Customers pay on delivery with local currency. World Shop is a similar service provided by TNT (www.tntworldshop.com).

The rapid adoption of these different EPSs in Kuwait and other Gulf countries are fueled by several factors: (i) strong economic growth since Kuwait and other GCC countries are among the highest GDP per capita in the world, (ii) high liquidity because of high oil prices, (iii) rising consumer expenditure because of high income salaries, (iv) rapid expansion of consumer credit because GCC countries have a free market economy that encourage consumption, (v) high internet and mobile phone penetration rate, and (vi) emergence of a young and highly educated population with explicit and sophisticated expectations in terms of payment services.

\section{A Subset of Past Studies on Electronic Payment and Obstacles Toward E-Shopping}

Ho and Ng 18 compared perceived risk across three EPSs (cash, credit card and an electronic fund transfer at pointof-sale) in Hong Kong. Based on a sample of 177 users they found that consumers prefer to use cash because it has a universal acceptance at all purchase situations. They also found that point-of-sale systems exhibit the higher perceived risk than other EPS.

Stroborn et al. 39 discussed nine commercial EPS available in Germany. These are: invoice, direct debits, credit cards, cash on delivery, collection systems, mobile payment, transfer in advance, and prepaid systems. They also assessed perceived preferences and obstacles toward these alternatives by a sample of 6000 Internet users. They found the online invoice payment system (55\%) was the most used one, followed by debit cards $(15 \%)$, credit card $(12 \%)$, COD $(10 \%)$, mobile payment $(1 \%)$, while prepaid cards were not used at all by the respondents $(0 \%)$. Among drivers they found that low cost of transactions, easy to use, coverage in case of damage and data protection, are all among the most frequently cited by the participants. Also results revealed that participants selected EPS for the following criteria in term of importance: no/less cost (71\%), possibilities of cancellation (62\%), easy to handle 
$(62 \%)$, charge time $(59 \%)$, coverage in case of damage (59\%), scale of personal data $(42 \%)$, transaction control $(41 \%)$, time spent on transaction $(18 \%)$.

Hassanein and Head 17 studied drivers and factors that inhibit customer to shop online. They found that reasons for shopping online include: convenience, product/service not available offline, better price, and curiosity. As for not shopping online they found: lack of trust, privacy concern violations, security concerns, no credit cards available, prefer shopping offline, difficulties to evaluate products online.

Laudon and Laudon 23 discussed several characteristics of successful EPSs in order to get their "widespread acceptance" among potential customers. These are: (i) independence (no need for specific software); (ii) interoperability and portability (EPS can be used across a variety of platforms); (iii) security; (iv) anonymity (need to maintain consumer privacy and anonymity); (v) divisibility (system will be widely accepted if it can handle small or large amount; e.g. credit card will not accept payment of less than \$3); (vi) ease of use (complex system are likely to be disconnected); and (vii) transaction fees (credit cards charge 3\% of the item purchase's price, which discourages merchants to accept this method for small purchases, and leave door open for competing alternative EPSs).

Guseva 14 studied drivers to adopt B2C e-commerce systems by 204 European frequently online purchasers. Results revealed that the availability of variety of EPS over B2C web sites (mean rank 7.76 out of 10) was ranked second in term of most important criteria after high security standards (average 8.2 out of 10). The degree of clarity and transparency of purchasing procedures (average 6.76 out of 10), and the availability of online help and support during the e-commerce transactions (average 4.83 out 10) were ranked successfully third and fourth in term of importance.

Other studies focused on other issues related to EPS. For example, Tsiakis and Sthephanides 43 discussed security and trust issues that are essential for EPS acceptance. Ramayah et al. 30 examined intention to use an online bill payment system in Malaysia. They found that perceived risk is an obstacle toward using this system. Schierz et al. 37 developed a model that explains consumers' acceptance of mobile payment services in Germany. They found that perceived security is an important factor that drives on intention to use m-payment. Kim et al., 21 examined effect of perceived trust, perceived security and their causes on intention to use EPS system in Korea. They found that both perceived security and perceived trust affect current use of EPS. However, their study focused mainly on debit and credit cards. Low familiarity with the EPS provider could also hinder the e-commerce adoption 12.

\section{Barriers to Ecommerce in the Arab World}

Different issues related to e-commerce were studied by Arab researchers including e-banking adoption 454647, ecommerce adoption 4449, and mobile payment adoption 31323435.

With regard to e-banking adoption in Kuwait Aladwani 47 found that Internet security, online banking regulations, consumer information privacy, and bank reputation are considered as the primary challenges toward adoption of online banking. Al-Hajri 45 investigated drivers and obstacles toward adoption of e-banking in Oman. He found that lack of customer trust and their low awareness about Internet technology are seen as the most disablers of e-banking adoption. Al-Somali et al. 46 found that lack of trust, awareness of online banking services, internet connection quality, social influence, resistance to change, education and computer self-efficacy are the main obstacles toward ebanking in Saudi Arabia.

As for ecommerce adoption in the Arab countries, Aladwani 44 found that both Arab customers and businesses are considering Internet security, customer privacy, trust, and service quality as barriers to e-commerce. Sait et al. 49 found that among factors that that inhibit B2C web sites adoption in Saudi Arabia are security and privacy. Henari and Mahboob 48 found that security and privacy, lack of regulations regarding the Internet, lack of trust, language barriers, and fear related to expectations in services and products not being met all represent obstacles that limit ecommerce adoption in Bahrain.

As for EPSs adoption in the Arab world Rouibah 35 studied factors affecting mobile payment adoption in Kuwait. $\mathrm{He}$ found that real demonstrations of mobile payment services affect positively perceived usefulness, trust, 


\section{Issues in Information Systems \\ Volume 16, Issue II, pp. 149-160, 2015}

enjoyment and familiarity which increase intention of consumers to use mobile payment. But the study found little effect of privacy protection on intention to use mobile payment. Rouibah 32 studied effect of gender and familiarity/experience on the adoption of a new mobile technology "Mnet" in Kuwait. He found that gender, trust and familiarity have a strong influence on Mnet adoption. Rouibah 31 reported on the factors that led Mnet to be a failure in Kuwait. He found that lack of perceived critical mass by merchants and customers is the main cause failure of Mnet mobile technology. Other studies focused on factors that lead merchants to use EPS in Jordan 16.

AL-ma'aitah and and Shatat 1 studied the effect of security factors (authentication, authorization, privacy protection, encryption) on perceived security of e-finance transactions in Jordan. They found these four factors have strong influence perceived security of EPSs which translate in more intention to use them.

A recent study was conducted by MasterCard 26 about the behavior of online consumers in six GCC Middle East countries 26. Data was collected late 2013 and the sample includes the behavior of 3000 consumers. Findings of the study about Kuwait online shoppers show the following behavior: the most important purchases include travel and tourism, financial advisory services, booking hotels, airline tickets, and clothes. 35\% use internet for shopping (increase $8 \%$ compare to 2012 ), $44 \%$ at least did a purchase transaction over the last three months. $71 \%$ indicated the convenience and ease of use of EPS is an important factor when they purchase over internet. $83 \%$ indicated they are satisfied about their online purchase experience. $90 \%$ use their Smartphone when they purchase online (compare to $74 \%$ in 2012). 54\% prefer to shop from local B2C (booking.com and cinescape.com are the preferred ones) rather than foreign web sites (e.g. Amazon.com). Results also reveal additional important factors. Security, reputation, and convenience/ ease of use of the EPS provider are the most important drivers toward online purchasing. With regard to how improving the online shopping experience of participants, securing the EPS was rated the highest one among the sample.

From the review of the above listed studies we can point out the following observations. First more studies investigate factors that affect intention to adopt EPS outside the Arab world than in the Arab world. Second, more studies in the Arab world focused on factors that drive or inhibit the adoption of ecommerce than that on EPS. Third while there are several EPS that ease ecommerce in Kuwait it is still unknown which EPSs are used, which get more satisfaction, and which systems not currently in use customer are willing to use in the future. Fourth, it is not also known which factors lead customers to use or not use these EPS in Kuwait. Fifth, while there are a variety of available EPS, it is unknown which obstacles inhibit their use.

\section{RESEARCH METHODOLOGY}

A questionnaire was developed to measure consumer perceptions about thirteen EPS available in Kuwait in term of current use, potential use, satisfaction with use and perceived obstacles. Each item was assessed on five-point Likert scales ranging from strongly disagree (1) to strongly agree (5) and with neutral as the midpoint. The questionnaire was pilot-tested by a convenient sampling with 30 undergraduate students involved in an ecommerce class. The instrument was also pilot tested with four professors. The results of the pilot tests were evaluated by using Cronbach's reliability and factor analysis. The standard lower bound for Cronbach's alphas is 0.7015 .

\section{Data Collection and Procedure}

The survey was administrated via two different modes: On online mode and a paper-based mode. The first mode is a web-based survey that was designed and posted via Qualtrics.com. The questionnaire collection was kept running continuously for one month. The author administrated the online questionnaire via e-mail to a mailing list of 1000 individuals from a leading business administration school, which includes students and employees. Those who did not respondents were sent an automatic e-mail reminder two times successfully. The survey was attached with a letter that explained the objectives of the study. The second method is a paper-based questionnaire that was distributed to 240 students enrolled in eight classes about an introductory course about management information system in two business administration schools in Kuwait. 350 complete and accurate questionnaires were selected from this study. 200 represent the paper-based survey and 150 from the online survey.

\section{Barriers Construct Validity}


We reused existing measures from 163248 and we update them to fit the context of perceived obstacles. The reliability of the instrument based on Cronbach reveals the following numbers: perceived use $(\alpha=0.894)$, satisfaction $(\alpha=0.914)$, intention to use EPS $(\alpha=0.907)$, and perceived obstacles $(\alpha=0.849)$. These high numbers indicate high stability and consistency of the questionnaire instrument 15 .

\section{Participants in the Study}

Most participants are female $(65.4 \%)$, young $(94.3 \%$ are less than 25 years), well educated $(82.3 \%$ are students, $14.3 \%$ hold a bachelor degree and $3.4 \%$ have a master degree), and are frequent internet users $(57.4 \%$ use internet up to 3 hours a day against) and $54.3 \%$ purchase less than 5 times per year

\section{RESULTS}

\section{What Current EPSs are Used in Kuwait?}

Figure 2 34shows the mean of thirteen EPS available in Kuwait. According to this figures the most important EPS currently in use are: debit cards, credit cards, cash on delivery, shop and ship service, prepaid Petronet card, mobile payment, prepaid internet bank cards, and e-kiosks. The famous PayPal and CashU.com online payment systems are not ranked among the top used in Kuwait. They are used only by limited sample users. In addition, figure 2 shows that the least used EPS are electronic check from Western MoneyZap, the cash on delivery world shop and payment over the prepaid Civil ID cards.

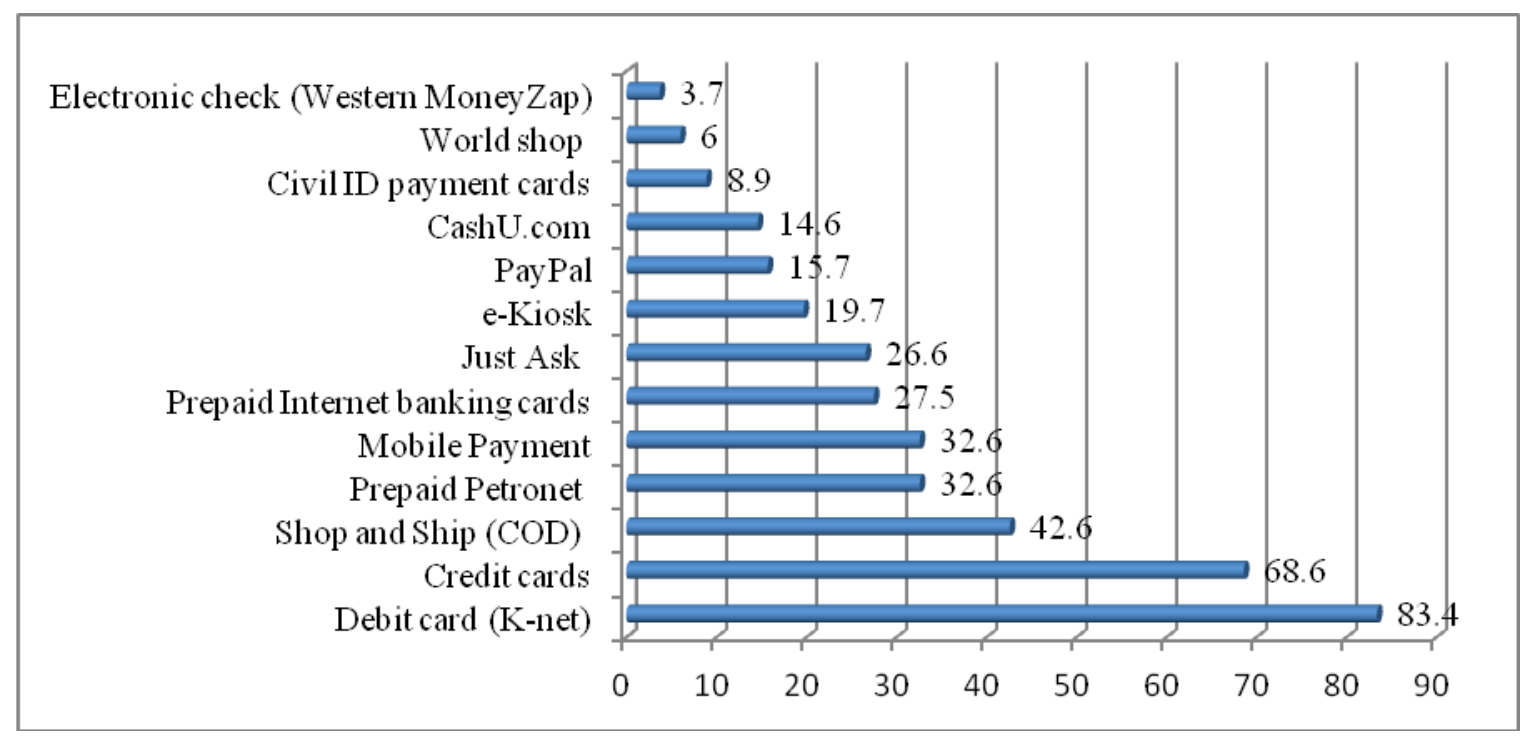

Figure 2. Degree of Usage of Different EPSs in Kuwait

\section{What is the Degree of Satisfaction with Current used EPS in Kuwait?}

Figure 3 shows the degree of satisfaction with the thirteen EPS system in use. It shows that perceptions of participants did not much change compare to figure 1. Figure 3 reveals that payment with debit cards (Knet), credit cards, cash on delivery shop and ship service, payment with prepaid Petronet, and mobile payment are among the top EPS that received high satisfaction. CashU and PayPal still receive little satisfaction compare to other EPS. And the least EPS that received very little satisfaction are payment with electronic check Western money zap, payment with cash on delivery World shop and payment via e-kiosks. 


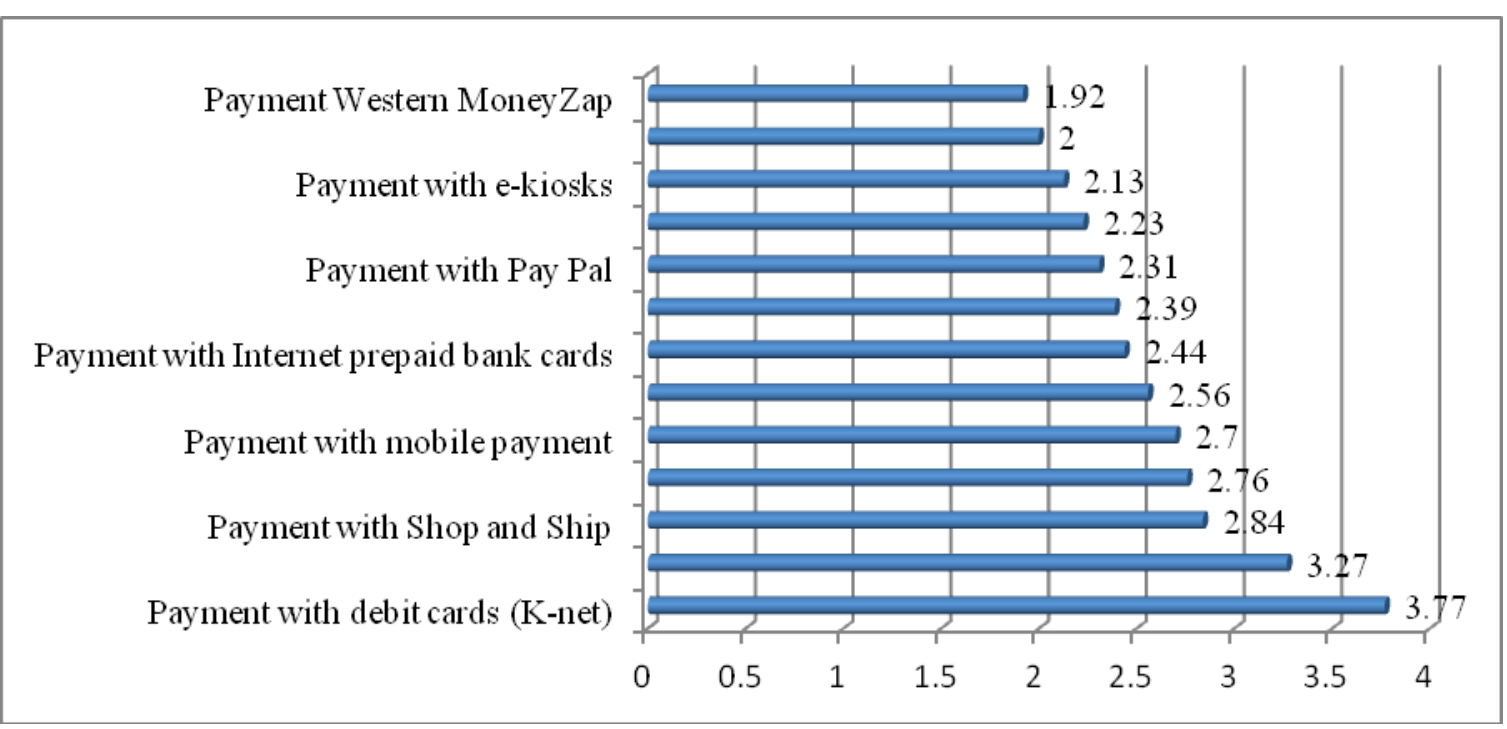

Figure 3. Degree of Satisfaction with Different EPS Alternatives

\section{What is the Intention to Use EPSs During the 12 Coming Months?}

Figure 4 shows that the five top EPS, not currently in use, participants intent to use during the next 12 months are successively: prepaid CashU.com, followed by payment over their Civil ID, cash on delivery Shop \& Ship service, PayPal, internet prepaid banks cards. It can be seen that cash on delivery services (Just Ask and world shop) are not on the agenda and not among the top planned EPS to be used. It can also be seen that electronic checks Moneyzap is the least EPS that participants plan to use, which reveal that it is not widely known in Kuwait.

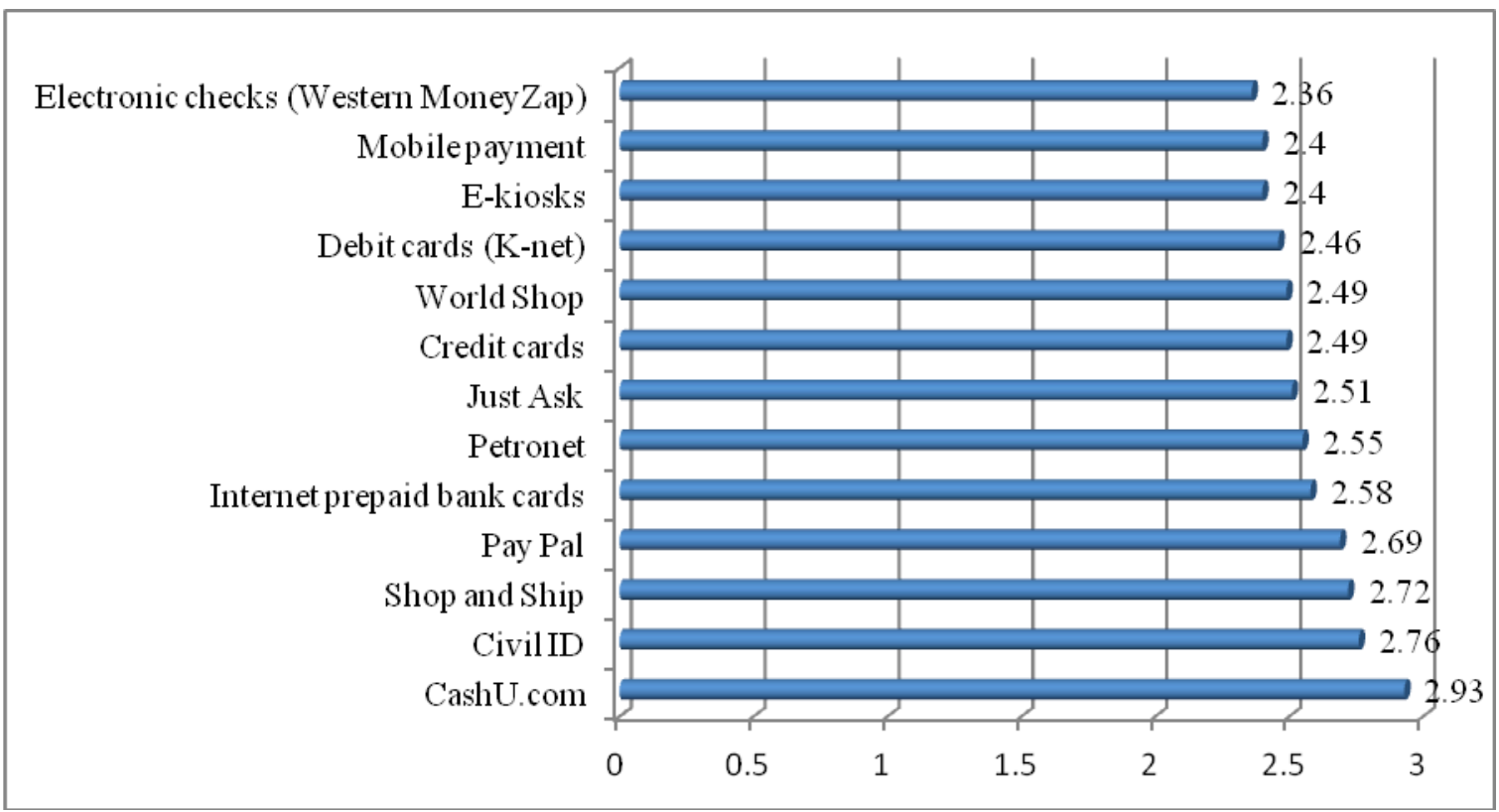

Figure 4. Intention to Use EPSs During the 12 Next Months

\section{What Obstacles Toward EPSs Do Customers Perceive in Kuwait?}

Table 1 shows the ranks of eighteen perceived obstacles (from the most severe to the least) by the sampled participants. Among these obstacles, only one fails to score above the cut point of 2.5; neutral, i.e. neither agree nor 


\section{Issues in Information Systems \\ Volume 16, Issue II, pp. 149-160, 2015}

disagree, which means it is not perceived as an obstacle. This obstacle is relates to the lack of a credit card to purchase online. In addition, the results also reveal the five top obstacles to be related to following: (1) Security threats caused by potential hackers' activities; (2) lack of security relation to ensuring confidentiality, integrity and non-denial purchases made through e-shopping sites. (3) fear of failure to fulfill the services and products posted on websites; it seems that participants exhibit low trust perceptions toward B2C web site procedures available on these web sites; (4) fear to be charged more than the price of the goods available on the site; (5) lack of reputation and familiarity of EPS service provider and lack of information available about them. This is a serious issue facing some EPS provider such as Cash On Delivery (Shop and ship, World Shop and Just Ask services). While they overcome paying with the foreign currencies, these service providers enable customers in Kuwait to shop online even from foreign $\mathrm{B} 2 \mathrm{C}$ web sites and pay with local currencies. However low familiarity and reputation of these companies make their service not well known among potential customers.

The least five perceived obstacles are related to: (i) barriers language since some online payment do not offer GUI in Arabic language; (ii) Procedures to pay with EPS alternatives are complex since PayPal and CashU.com both require to opening an account, transfer money to these account, use a strong password (more than 7 characters with the preference to be alphanumeric characters) and to change it on regular basis to protect it from hacking activities; (iii) consumer privacy is violated, in fact many organizations in Kuwait acquire consumers personal information with illegal ways and then contact these consumers for marketing purposes such as restaurants, hotels etc. (iv) Consumer will be charged high cost when paying with EPS. This is the case mainly of credit cards which charge 3\% of purchases in Kuwait. CashU.com is also a convenient EPS to pay for online purchases when you don't own credit cards. However, despite its convenience the exchange rate (from Emirati Dirham to Kuwait Dinar) is high compare to other EPS systems. (v) Last obstacle is related to complexity of dealing with EPS interfaces. Since participants in the survey are not all have a high computer literacy, it is obvious that some of them face problems to follow the procedure to complete the e-payment transactions. This is mainly the case of CashU and PayPal.

Table 1. Perceived Obstacles Toward using EPSs

\begin{tabular}{|l|c|c|}
\hline \multicolumn{1}{|c|}{ Perceived Obstacles } & Mean & SD \\
\hline 1. Risk of breaches by hackers & 3.58 & 1.25 \\
\hline $\begin{array}{l}\text { 2. Lack of protection to ensuring confidentiality, integrity and non-denial purchases } \\
\text { made B2C web sites }\end{array}$ & 3.39 & 1.19 \\
\hline 3. Fear of failure to fulfill the services and products posted on websites & 3.37 & 1.1 \\
\hline 4. Fear to be charged more than the price of the goods available on the web site & 3.2 & 1.24 \\
\hline 5. EPS providers are not famous and lack of information available about them & 3.15 & 1.24 \\
\hline 6. Lack of awareness about the availability of EPS providers & 3.14 & 1.25 \\
\hline 7. EPS providers are not well known among consumers and stores & 3.11 & 1.07 \\
\hline 8. Fear not fulfill products and services requested by customer & 3.1 & 1.15 \\
\hline 9. Lack of trust toward EPS & 3.1 & 1.25 \\
\hline 10.Prefer to pay cash instead of EPS while shopping & 3.09 & 1.28 \\
\hline 11. Lack of awareness of the availability of EPS on the portal of e-government & 3.08 & 1.05 \\
\hline 12. Lack of regulations related to Internet use & 3.05 & 1.16 \\
\hline 13.Difficulties of dealing with EPS interfaces & 2.91 & 1.12 \\
\hline 14. Consumer will be charged high cost when paying with EPS & 2.9 & 1.08 \\
\hline 15. Consumer privacy is violated & 2.85 & 1.1 \\
\hline 16.Procedure to pay with EPS is complex & 2.69 & 1.09 \\
\hline 17. Barriers language when using EPS & 2.64 & 1.18 \\
\hline 18. Don't have a credit card & 2.39 & 1.46 \\
\hline
\end{tabular}




\section{Issues in Information Systems}

Volume 16, Issue II, pp. 149-160, 2015

\section{Results Discussion}

Our results show differences with regard to customer's preferences of variety of EPS available in Kuwait compare to those studied by past studies, such as Ho and $\mathrm{Ng} 18$ who found that consumers in Hong Kong prefer to use cash instead of EPS, Stroborn et al. 39 who found that online invoice payment system are the most used one. In addition, our results extend these findings since they go beyond simply assessment of customers' preferences toward existing EPS but to also include level of satisfaction, intention to use, and perceived obstacles.

With regard to EPS obstacles, our results confirm findings of pas studies who found that perceived risk is among important inhibitors toward intention to use different EPS such as online bill payment system in Malaysia 30, mpayment in Germany 37, debit and credit cards in Korea 21, e-finance transactions in Jordan 1. Other obstacles were also found such as lack of customer trust toward using debit and credit cards in Korea 21, mobile payment in Kuwait 35, lack of convenience and complexity of EPS 26. Also our findings extent results of Stroborn et al. 39 who found that among obstacles perceived by German customers when using different EPS they found excessive charge, inability to cancel purchases, complexity to use, are among obstacles felt. Another contribution of this study is that it provides assessment of different drivers toward acceptance of EPS provided by Laudon and Laudon 23 who discussed several motives to use EPS but did not provide how customers perceive them. In addition, our results also provide support for previous studies that focused on ecommerce drivers and obstacles. In particular our finding support those of Guseva 14 who found that high security and availability of variety of EPS over B2C web sites are the most important drivers to motivate customers to engage in B2C e-commerce. Finally our findings also support studies in the Arab world that found lack of trust 174445 46, security concerns 17444948 are obstacles toward ecommerce.

\section{CONCLUSIONS}

This study focuses on thirteen different EPS available in Kuwait which were categorized into three categories: prepaid, pay now and pay latter. The main focus was on which EPSs were mot used, which ones receive high satisfaction, which EPS not currently in use will be used in the 12 coming months, and perceptions of participants with regard to eighteen obstacles when they use theses different EPS.

This study achieves five contributions. First, this is the first study in the Arab world that shows most used EPS. Second, contribution consists to show the most used EPS that received high satisfaction. Third contribution consisted to shed light on EPS not currently used and that consumer intent to use in the next coming 12 months. The fourth contribution is the identification of the most perceived obstacles toward using alternative EPS. The most perceived obstacles are related to risk perceptions, lack of law and regulations that protect online consumers, lack of security protection, lack of failure to fulfill the services and products are promised and lack of reputation of EPS service provider.

This study suffers from two limitations. The first one is related to time of data collection since it collected data only on one time. In order to shed more light on the acceptance and satisfaction, it is suggested to gather perceptions of consumers across time in order to highlight changes in habits. The second limitation is related to the level of educations of participants. The study targeted highly educated consumers and ignore consumers with little computer literacy.

This study has several management and research perspectives. From a management perspectives, it reveals which EPSs are currently in use versus those not in use, and which ones get high satisfaction. These EPS (e.g. Cash On delivery provided by World Shop, and Just Ask or CashU.com) may become the target of marketing campaign in order to boost their use.

With regard to research perspective, this study reveals that CashU.com is among the top EPS that participants plan to use in the next coming 12 months. Future perspective could be oriented toward understanding trust factors that increase intention to use this type of EPS. Arab culture is identified by four characteristics: (i) It scores high on uncertainty avoidance; (ii) It has preference for face to face transactions instead of virtual ones; (iii) Arab people exhibit high trust and life enjoyment; and (iv) they have tendency to be the first to try using new technologies commonly known as personal innovativeness 33. Following these characteristics, this study encourages future studies to focus only on CashU.com and study the effect of the four factors: third party seal in EPS commonly 
known as "trust logo" or "SSL badges" 21, familiarity 22, propensity to trust 12, and perceived enjoyment in EPS 42 on intention to use CashU via the mediation of consumer trust.

\section{ACKNOWLEDGEMENTS}

This research was funded by Kuwait University, Research Grant IQ 01/10. The author acknowledges the Research Administration Project for its support.

\section{REFERENCES}

1. AL-ma'aitah M. \& and Shatat A (2011). Empirical Study in the Security of Electronic Payment Systems. International Journal of Computer Science Issues 8(4), 393-401

2. Appiah A., \& Agyemang F., (2006). Electronic Retail Payment Systems: User Acceptability and Payment Problems in Ghana. Master Thesis Business Administration, School of Management Business Administration Blekinge Institute of Technology, Sweden, Web: http://www.bth.se/fou/cuppsats.nsf/1d345136c12b9a52c1256608004f0519/2317be39b43b8abfc125712a003974 64 ! OpenDocument

3. Association for Financial Professionals -AFP (2004). Electronic payments survey. Web: www.afponline.org

4. Centeno C. (2002). Building Security and Consumer Trust in Internet Payments - The potential of "soft" measures. Background Paper No. 7 Electronic Payment Systems Observatory (ePSO); [online] web http://ftp.jrc.es/EURdoc/eur20278en.pdf

5. Chou Y., Lee, C., \& Chung, J., (2004). Understanding m-commerce payment systems through the analytic hierarchy process. Journal of Business Research 57(12): 1423- 1430.

6. Cotteleer, M. J., Cotteleer, C. A., \& Prochnow A. (2007). Cutting checks: challenges and choices in B2B epayments. Communications of the ACM, 50(6) 56-61.

7. Dahlberg T., Mallat N., Ondrus J., \& Zmijewska A., (2008). Past, present and future of mobile payments research: A literature review. Electronic Commerce Research and Applications 7(2): 165-181

8. Dai X., \& Grundy, J. (2007). NetPay: an off-line, decentralized micro-payment system for thin-client applications. Electronic Commerce Research and Applications 6, 91-101.

9. Economy Watch (2013). Kuwait Telephone Statistics: Number of Fixed Lines, Mobile Phone Penetration Rate, web: http://www.economywatch.com/economic-statistics/kuwait/Telephone_Statistics/. Accessed September 2013

10. Elsidafy, M. (2009). E-commerce in UAE to hit $\$ 36 b n$ by 2010 . http://www.emirates $247 . c o m / 2.308 / \mathrm{q}-\mathrm{a} / \mathrm{e}-$ commerce-in-uae-to-hit-36bn-by-2010-2009-07-05-1.27937

11. Fong M. W. L. (2003). Bankcard Payment System in the People's Republic of China. Annals of Cases on Information Technology, 184-200, Chapter 12

12. Gefen D. (2000). E-commerce: the role of familiarity and trust. Omega, 28(6), 725-737

13. Gholami L., Ogun A., Koh E., \& Lim J., (2010) Factors affecting e-payment adoption in Nigeria. International Journal of Handheld Computing Research 2(1), 51-67

14. Guseva N. (2010). E-commerce system's quality criteria: Customer Approach. Proceedings of the Ebee Conference, Turkey 26-28 ${ }^{\text {th }}$ May 2010.

15. Hair J.F., Anderson R.E., Tathan R.L \& Black W.C. (1998). Multivariate data analysis, 5th Edition, PrenticeHall, Englewood Cliffs, NJ

16. Halaweh M., \& Fidler C., (2008). Adoption of electronic payment systems in ecommerce websites within Jordan. IADIS Multi-conference On Computer Science and Information Systems, 71-77

17. Hassanein K., \& Head M., (2007). Manipulating perceived social presence through the web interface and its impact on attitude towards online shopping. Int. J. Human-Computer Studies 65; 689-708

18. Ho S.M \& Ng V.T.F. (1994). Customers' Risk Perceptions of Electronic Payment Systems. International Journal of Bank Marketing 12 (8), 26 - 38

19. Hsieh, C. (2001). E-commerce payment systems: critical issues and management strategies. Human Systems Management 20, 131-138

20. Hwang, R., Shiau, S., \& Jan, D. (2007). A new mobile payment scheme for roaming services. Electronic Commerce Research and Applications 6, 184-191 


\section{Issues in Information Systems}

Volume 16, Issue II, pp. 149-160, 2015

21. Kim C., Tao W., Shin N., \& Kim K. (2010). An empirical study of customers' perceptions of security and trust in e-payment systems. Electronic Commerce Research and Applications 9(1), 84 - 95

22. Kim D.J, Ferrin D.L., \& Rao H.R., (2008). A trust-based consumer decision-making model in electronic commerce: The role of trust, perceived risk, and their antecedents. Decision Support Systems, 44, 544-564

23. Laudon K.C., and Laudon J.P., (2008). Management Information Systems, The digital firm $10^{\text {th }}$ Edition

24. Lin S.J., \& Liu D.C. (2009). An incentive-based electronic payment scheme for digital content transactions over the Internet. Journal of Network and Computer Applications 32(3), 589-598

25. Lixin Y., Lishan A., \& Jun T. (2011). Risk-based AML regulation on Internet payment services in China. Journal of Money Laundering Control 14(1), 93-101

26. Mastercard (2014). Behavior of online shopping in Middle East. MasterCard Study published summary results in AlQabas.com.kw newspaper $27^{\text {th }}$ March 2013

27. McHenry, W. \& Borisov, A. (2005). E-government public-private partnerships: the 'Gorod' payments system in Siberia. Journal of Enterprise Information Management 18 (5), 625-40

28. Ozkan S., Bindusara, G., \& Hackney, R. (2010). Facilitating the adoption of e-payment systems: theoretical constructs and empirical analysis. Journal of Enterprise Information Management 23 (3), 305-325

29. Peffers K., \& Ma W., (2003). An agenda for research about the value of payment systems for transactions in electronic commerce. Journal of Information Technology Theory and Application 4(4), 1-14

30. Ramayah T., Ling C.Y., Suki N.M. \& Ibrahim A., (2005). Determinants of Intention to Use an Online Bill Payment System among MBA Students. E-Business $9,80-91$

31. Rouibah (2009). The Failure of Mobile Payment: Evidence From Quasi-Experimentations. Proceedings of The 4th Euro American Conference on Telematics and Information Systems (EATIS 2009), Prague, Czech Republic on 3 - 5 June, 2009.

32. Rouibah K. (2010). Consumer Intention to Use mobile payment services: A field study of some acceptance factors in Kuwait [Arabic version]. Arab Journal of Administrative Sciences 17(2), 229-275

33. Rouibah K., \& Abbas H., (2010). Effect of personal innovativeness, attachment motivation and social norms on the acceptance of camera mobile phones: An empirical study in an Arab country. International Journal of Handheld Computing Research 1, 4, $41-62$

34. Rouibah K., \& Hasan A., (2012). Advancements of e-payment for e-commerce in the State of Kuwait: obstacles of usage and user satisfaction [In Arabic] Journal of The Gulf and Arabian Peninsula Studies 146(38),111-194

35. Rouibah K., (2007). Does mobile payment technology Mnet attract potential consumers? The case of Kuwait, Proceeding of the 18th Australasian Conference on Information Systems, 199-211, 5-7 Dec 2007, Toowoomba, Australia

36. Schaupp L.C., Carter L., \& McBride M.E. (2010). E-file adoption: A study of U.S. taxpayers' intentions. Computers in Human Behavior 26(4) 636-644

37. Schierz P. G.Schilke, O., \& Wirtz, B.W. (2010). Understanding consumer acceptance of mobile payment services: An empirical analysis. Electronic Journal Research and Applications (9), 209 - 216.

38. Simon J., Smith K., \& West T., (2010). Price incentives and consumer payment behaviour, Journal of Banking \& Finance 34(8), 1759-1772

39. Stroborn K., Heitmann A., Leibold K.,\& Frank G., (2004). Internet payments in Germany: a classificatory framework and empirical evidence. Journal of Business Research 57, 1431- 1437

40. Szmigin I., and Bourne, H., (1999). Electronic cash: a qualitative assessment of its adoption. International Journal of Bank Marketing 17(4): 192-202.

41. Tan G.W., Ooi K., Chong S., \& Hew T. (2014). NFC mobile credit card: The next frontier of mobile payment? Telematics and Informatics 31(2), 292-307

42. Tella A. (2012). Determinants of E-Payment Systems Success: A User's Satisfaction Perspective. International Journal of E-Adoption, 4(3), 15-38, 15-38

43. Tsiakis T., \& Sthephanides G., (2005). The concept of security and trust in electronic payments. Computers \& Security $24(1), 10-15$

44. Aladwani A.M. (2003). Key Internet characteristics and e-commerce issues in Arab countries. Information Technology \& People, 16 (1), 9-20

45. Al-Hajri, S. (2008). The Adoption of E-banking: The Case of Omani Banks. International Review of Business Research Papers, 4 (5), 120-128. (L)

46. Al-Somali S.A., Gholami, R., and Clegg, B. (2009). An investigation into the acceptance of online banking in Saudi Arabia. Technovation, 29(2), 130-141. 
47. Aladwani A. (2001). Online banking: a field study of drivers, development challenges, and expectations, International Journal of Information Management, Vol. 21 No. 3, pp. 213-25

48. Henari T.F., d Mahboob, R. (2008). E-commerce in Bahrain: the non-technical limitations. Education, Business and Society: Contemporary Middle Eastern Issues, 1(3), 213-220

49. Sait S.M., Al-Tawil, K.M., and Hussain, S.A. (2004). E-commerce in Saudi Arabia: Adoption and perspectives. Australasian Journal of Information Systems, 12(1), 54-74. 